East Africa and South-East Asia, returning to Cambridge in 1946 to read social anthropology. He graduated in 1947 and was awarded an Emmanuel College seholarship. During 1948-49 he was education officer of the Overseas Food Corporation, Tanganyika. He then became a research assistant in the Faculty of Economic and Social Studies at the University of Manchester and was awarded an M.A.(Econ.) in 1951. In the same year he became a research scholar in the Department of Anthropology and Sociology at the Australian National University at Canberra, and during 1953-54 carried out field work in Northern Australia. He was awarded the degree of Ph.D. (Australian National University) in 1954. He then returned to Manchester as a research assistant for the next two years, and while in this University was awarded the Curl Bequest Essay Prize of the Royal Anthropological Institute (1955). In 1956 he became lecturer in sociclogy in the University of Hull and was promoted to the grade of senior lecturer in 1961. During the session 1960-61 he was director of northern research at the Centre for Community Studies in the University of Saskatchewan. Dr. Worsley's recent research interests have been concentrated mainly on work and power as themes for sociological research in Britain, and in this latter field he has concentrated on the trawling industry around Hull and on institutional élites.

\section{Psychology at the Royal College of Science and Technology, Glasgow: Prof. G. Jahoda}

Dr. Gustav JAHODA, at present senior lecturer in social psychology at the University of Glasgow, has been appointed to a professorship in psychology within the Frculty of Arts and Social Studies, at the Royal College of Science and Technology, Glasgow, as from January 1, 1964. He graduated B.Sc. Honours in Economies at the University of London in 1945 and was awarded the degrees of M.Sc. and Ph.D. in social psychology at London in 1947 and 1952 respectively. He is a Fellow of the British Psychological Society. Dr. Jahoda served in the French and British Armies during the Second World War and was released from service due to injury in 1943. In 1946, he was in charge of social research at "Common Ground" Educational Film Strips before joining the University of Oxford Extra-Mural Delegacy as staff tutor in psychology in 1947. In 1949, he was appointed lecturer in social psychology in the University of Manchester, and, in 1952, beceme lecturer in social psychology in the then University College of the Gold Coast (now University of Ghana). He took up his appointment at Glasgow in 1956. Among Dr. Jahoda's research interests is a concern with problems of occupational choice facing adolescents in which he has carried out several studies, the most recent one leading to a fundamental critique of the present structure of the Youth Employment Service. Both in Africa and in Britain, he has been concerned with research into the development of thought-processes in children, especially the early origins of ideas about social class and nationality and their influence on adult attitudes, and is interested in the possibility of exploring this approach as an aid to the understanding of international attitudes and conflicts. Dr. Jahoda is at present engaged jointly with a colleaguo at Oxford on an international study of this problem supported by American funds.

Veterinary Pathology at the University of Edinburgh: Prof. A. Buxton

Dr. A. Buxton, at present senior lecturer in veterinary bacteriology in the University of Liverpool, has been appointed to the newly established chair of veterinary pathology in the University of Edinburgh. Dr. Buxton was educated at the Leys School, Cambridge, and the Royal Veterinary College, London, where he qualified M.R.C.V.S. in 1941. After a short period in general practice, Dr. Buxton served as a research officer in the
Central Veterinary Laboratory at Weybridge from 1943 until 1948, where be started a Salmonella Reference Centre. In 1948, he was appointed research officer with the Animal Health Trust at Houghton, Huntingdon, and from 1950 he worked in the University of Cambridge where he obtained a Ph.D. in 1952 for his work on immun ity in the chicken's egg. In the same year, Dr. Buxton was appointed lecturer in veterinary bacteriology at the University of Liverpool and in 1957 was promoted senior lecturer. In 1960 he obtained his Fellowship of the Royal College of Veterinary Surgeons for his work on the pathogenesis of salmonellosis in poultry. His particular research interests are in immunopathology with special reference to the pathogenesis of enteric infections. He is president of the British Veterinary Poultry Association, and a member of the World's Poultry Science Association, the British Society for Immunology, and the Society for General Microbiology. Dr. Buxton will take up his new appointment in August.

\section{Molecular Sciences in the University of Warwick}

Dr. V. M. Clark and Dr. T. C. Waddington have recently been pre-elected to professorships in the School of Molecular Sciences in the new University of Warwick. The term 'molecular scienees' has been ehosen to indicate the whole field of chemistry, and thus to avoid emphasis on the customary subdivisions of the subject.

Prof. V. M. Clark

DR. V. M. CLARK was born in 1925, and entered Gonville and Caius College in 1943, graduating with first-class honours in Parts I and II of the Natural Sciences Tripos in 1946. In 1948 he was elected a Research Fellow of his College, and spent 1949-50 in the Department of Cytophysiology at Copenhagen, and 1951-53 as a Rockefeller Foundation Fellow at Harvard, where he worked under Prof. R. B. Woodward. He took his Ph.D. degreo in 1949 at Cambridge, where he was afterwards appointed University demonstrator and then lecturer. He has been a visiting lecturer at the Polish Academy of Science, and a visiting professor at the Rockefeller Institute, New York, and the Technische Hochschule, Darmstadt. He has been a member of the Council of the Chemical Society, and was appointed Tilden Lecturer of the Society in 1963. The greater part of Dr. Clark's research has been carried out in collaboration with Lord Todd. The main subject has been studios on phosphorylation, on which since 1949 he has published about twenty papers. A second branch of research has been concerned with the synthesis of corrins: this has entailed a detailed preliminary investigation of the preparation and reactions of $\Delta^{1}$-pyrrolines, which has yielded novel and interesting results. He has also collaborated in work on the strueture and degradation of vitamin $\mathrm{B}_{12}$, and on the structure of the alkaloid ealycanthine and its degradation product calycanine.

Prof. T. C. Waddington

Dr. T. C. WADDINGToN was born in 1930, and was an Entrance Scholar of Gonville and Caius College (1949) and graduated with first-class honours in Parts I and II of the Natural Sciences Tripos (1952). His carly research whis carried out with Dr. Peter Gray at Cambridge, and after award of the Ph.D. degree and election to a Research Fellowship at his College, he worked during 1955-56 with Dr. W. G. Schneider at the National Research Laboratories, Ottawa. On his return to Cambridge he was awarded an Imperial Chemical Industries fellowship and elected at University demonstrator, a tutor in his College and later a University lecturer. He was awarded the Meldola Medal of the Royal Institute of Chemistry in 1959. His earlier research was on the structure, thermochemistry and reactivity of the inorganic azides, and led to his interest in the calculation of the lattice energies of ionic solids. In Canada he worked on the photoconductivity of organic 